\title{
Impact of modern chemotherapy on the survival of women presenting with de novo metastatic breast cancer
}

\author{
Sumanta K Pal ${ }^{1 *}$, Mary Dehaven ${ }^{1}$, Rebecca A Nelson², Susan Onami ${ }^{1}$, JoAnn Hsu', Sarah Waliany ${ }^{1}$,
} Laura Kruper ${ }^{3}$ and Joanne Mortimer ${ }^{1}$

\begin{abstract}
Background: Data that directly associate utilization of novel systemic therapies with survival trends in metastatic breast cancer (MBC) are limited. In the setting of de novo MBC, large registry analyses cite positive temporal trends in survival, but the extent to which advances in systemic therapy have contributed to these gains is not clear.

Methods: The City of Hope Cancer Registry was used to identify a consecutive series of patients with de novo MBC who received their first line of therapy between 1985 and 2004. Comprehensive clinicopathologic and treatment-related data were collected for each patient. Univariate analyses were conducted via Cox regression to identify factors associated with improved survival. Multivariate analysis was also conducted via Cox regression and the stepwise procedure was used to identify independent predictors of survival.

Results: A total of 324 patients with de novo MBC were identified. After application of exclusion criteria, including the sole presence of supraclavicular node metastasis, 274 patients were retained in the analysis. The

treatment-related characteristics associated with improved survival included: use of endocrine therapy (hazard ratio [HR] 0.60, 95\% $0.47-0.77 ; \mathrm{P}<0.0001$ ), and addition of bisphosphonates (HR 0.70, 95\%Cl 0.52-0.96; $\mathrm{P}=0.02$ ). However, recipients of novel cytotoxic agents (defined as drugs approved for MBC since 1994) had no improvement in survival relative to patients treated with older cytotoxic agents. On multivariate analysis, age $(<50)$, receipt of aromatase inhibitors, and receipt of zoledronic acid were independent predictors of survival.
\end{abstract}

Conclusions: The overall survival of women with de novo metastatic breast cancer has improved over the past 20 years. However, the contribution of conventional cytotoxic agents to this improvement is minimal.

Keywords: Chemotherapy, Endocrine therapy, Survival, Metastatic breast cancer, Stage IV

\section{Background}

Over the past 30 years, the survival of women with early stage breast cancer has been prolonged [1]. In addition to earlier detection, the use of adjuvant chemotherapy and endocrine therapy following definitive surgery and radiation therapy is credited with a significant improvement in overall survival. However, these same systemic therapies that prolong the survival of women with early stage disease are only palliative in metastatic disease. For women with metastatic HER2 positive breast cancers,

\footnotetext{
* Correspondence: spal@coh.org

'Division of Genitourinary Malignancies, Department of Medical Oncology \& Experimental Therapeutics, City of Hope Comprehensive Cancer Center,

Duarte, CA, USA

Full list of author information is available at the end of the article
}

the addition of trastuzumab to first line chemotherapy has been shown to both prolong both the disease free and overall survivals [2]. Shortly after the FDA approved trastuzumab for metastatic breast cancer (MBC), an FDA panel was convened to review the indications for approving new agents as first-line therapy in advanced breast cancer. The committee recommended that improvement in overall survival should be demonstrated for an agent considered for the first line treatment of advanced breast cancer [3].

Since 1994, a number of agents have been shown to be active in advanced breast cancer. These include: paclitaxel, docetaxel, capecitabine, vinorelbine, gemcitabine, nab-paclitaxel, and ixabepilone [3]. The recent debate about the use of bevacizumab in breast cancer has

\section{Biomed Central}


forced us to re-evaluate the risk benefit ratio of our interventions and to question if prolongation in overall survival is a realistic benchmark for all new agents [4].

The goal of this study was to assess the impact of newer chemotherapy agents on overall survival of women with newly diagnosed de novo metastatic disease (i.e., primary distant $\mathrm{MBC}$ ). Several other investigators have used existing databases to determine whether advances in systemic therapy have improved patient survival over different time intervals [5-10]. These studies have generally included both women who developed recurrent disease after adjuvant chemotherapy and/or endocrine therapy and patients treated with endocrine therapy. Using the City of Hope Cancer Registry, we compared the overall survival of women with de novo metastatic breast cancer treated between January 1, 1985 and December 31, 1994 with the overall survival of women diagnosed between January 1, 1995 and December 31, 2004 with attention to the impact of chemotherapy on disease outcome.

\section{Methods}

\section{Patient selection}

A consecutive series of patients with de novo $\mathrm{MBC}$ were identified from the City of Hope $(\mathrm{COH})$ Cancer Registry through an IRB approved protocol. The registry houses data on all patients who receive cancer treatment at the institution. This database has been maintained for over three decades and includes patient demographic information and disease-related variables, including diagnosis, date of diagnosis, pathologic assessment, sites of metastasis, and type/modality of treatment. Disease and vital status are updated at least annually, and date of last follow-up or death is recorded. Vital status is confirmed by either cross-referencing clinician reports or the Social Security Death Index. Patients eligible for the current analysis were those with de novo MBC diagnosed between January 1, 1985 and December 31, 2004. For consideration in the current study, patients were required to have stage IV breast cancer as defined by the American Joint Committee on Cancer (AJCC) Cancer Staging Manual $\left(6^{\text {th }}\right.$ Ed) [9]. A relevant change in this edition was designation of ipsilateral supraclavicular node involvement as N3 disease (previously considered M1 disease). Thus, patients diagnosed with stage IV disease on the basis of ipsilateral supraclavicular node involvement alone were excluded from analyses. Medical records for each de novo $\mathrm{MBC}$ registry case was reviewed in full by the principal investigator (S.K.P) or trained associates (S.O.; S.W.) to ensure completeness and appropriateness for inclusion in the current study.

\section{Variables}

Variables obtained from the registry included date of birth, date of diagnosis, date of death or last follow-up, estrogen receptor (ER) and progesterone receptor (PR) status, human epidermal growth factor receptor 2 (HER2) status, tumor histology, and sites of metastases. As hormone receptor status was not reported consistently by the cancer registry prior to January 1, 1995, incomplete data were supplemented through review of pathology records. Hormone receptor status was assigned in the context of institutional reference ranges for the assay utilized. HER2 status, primarily available for patients diagnosed with breast cancer since 1998, was also obtained from the pathology records when not recorded in the registry. Patients were considered HER2-positive if immunohistochemical staining for HER2 was classified as $2+$ or $3+$ or the HER2/neu: centromere 17 ratio determined by fluorescence in situ hybridization (FISH) was $\geq 2.2$. Histology was classified as either inflammatory or non-inflammatory. Sites of metastasis were coded as liver, lung, brain, bone, supraclavicular node, and soft tissue. Thorough chart review was conducted for each patient to ascertain treatmentrelated data. To stratify patients based on receipt of older and novel cytotoxics, the most commonly used cytotoxic agents were divided into two categories (A and B), noted in Table 1. Endocrine therapy was segregated into use of selective estrogen receptor modulators (SERMs), AIs, luteinizing hormone releasing hormone (LHRH) analogues, and fulvestrant. Patients who were treated with lapatinib or trastuzumab were coded as receiving HER2-directed therapy. Bone-directed therapy with intravenous bisphosphonates was coded separately for pamidronic and zoledronic acid. To examine temporal trends, the cohort was divided into two groups based on date of diagnosis: (1) between January 1, 1985 and December 31, 1994 (Period A), and (2) between January 1, 1995 and December 31, 2004 (Period B). Stratification into these two time periods was predicated on the approval of paclitaxel in 1994 - after this time,

Table 1 Categorization of cytotoxic chemotherapies received during the study period

\begin{tabular}{lc}
\hline Category $\mathbf{A}$ & Category $\mathbf{B}$ \\
\hline 5-Fluorouracil & Capecitabine \\
Epirubicin & Docetaxel \\
Doxorubicin & Gemcitabine \\
Cyclophosphamide & Ixabepilone \\
Etoposide & Liposomal doxorubicin \\
Ifosfamide & Nab-paclitaxel \\
Methotrexate & Paclitaxel \\
Cisplatin & Vinorelbine \\
Carboplatin & \\
\hline
\end{tabular}

Novel agents were considered to be those approved since 1994 and are listed in Category B, while other available agents are included in Category A. 
those agents listed into Category B (see Table 1) also gained FDA approval.

\section{Statistical analysis}

Patients in each period were followed until the first of the following occurrences: death, date of last follow-up, or until 3 years after the end of the study period (i.e.,
December 31, 2008). Univariate analyses were performed by Cox regression to determine differences in survival for the following comparisons: period of diagnosis (Period A $v$ Period $\mathrm{B})$, age at diagnosis $(\leq 50 v>50)$, histology (inflammatory $v$ invasive ductal), ER status (positive $v$ negative), PR status (positive $v$ negative), HER2 status (positive $v$ negative), liver metastasis (yes $v$ no), lung

Table 2 Patient characteristics stratified by study period

\begin{tabular}{|c|c|c|c|c|c|}
\hline \multirow[t]{2}{*}{ Characteristic } & \multicolumn{2}{|c|}{ Period A $(n=151)^{*}$} & \multicolumn{2}{|c|}{ Period B $(n=123)$} & \multirow[t]{2}{*}{ P-value } \\
\hline & $n$ & $(\%)$ & $\mathrm{n}$ & $\%$ & \\
\hline Median age, years & 50 & & 51 & & 0.33 \\
\hline \multicolumn{6}{|l|}{ Histology } \\
\hline Inflammatory & 25 & $(17)$ & 27 & $(22)$ & \\
\hline Non-Inflammatory & 126 & (83) & 96 & (78) & 0.59 \\
\hline \multicolumn{6}{|l|}{ Site of Metastasis } \\
\hline Liver & 28 & (19) & 45 & $(37)$ & 0.30 \\
\hline Lung & 45 & (30) & 39 & $(32)$ & 0.24 \\
\hline Brain & 4 & (3) & 10 & (8) & 0.72 \\
\hline Bone & 84 & $(56)$ & 82 & $(67)$ & 0.008 \\
\hline Bone Only & 37 & $(25)$ & 31 & $(25)$ & 0.52 \\
\hline Supraclavicular Node & 55 & (36) & 34 & (28) & 0.20 \\
\hline Soft tissue & 20 & (13) & 22 & $(18)$ & 0.18 \\
\hline \multicolumn{6}{|l|}{ ER Status } \\
\hline Positive & 56 & $(63)$ & 75 & $(68)$ & \\
\hline Negative & 33 & $(37)$ & 34 & $(32)$ & 0.01 \\
\hline \multicolumn{6}{|l|}{ PR Status } \\
\hline Positive & 43 & $(48)$ & 54 & $(51)$ & \\
\hline Negative & 45 & $(52)$ & 53 & (49) & 0.75 \\
\hline \multicolumn{6}{|l|}{ HER2 Status } \\
\hline Positive & 1 & $(50)$ & 31 & (39) & \\
\hline Negative & 1 & $(50)$ & 32 & $(62)$ & 0.71 \\
\hline \multicolumn{6}{|l|}{ Receipt of Endocrine therapy } \\
\hline SERMS & 82 & $(54)$ & 52 & $(42)$ & 0.0002 \\
\hline $\mathrm{Al}$ & 19 & (13) & 46 & $(37)$ & 0.72 \\
\hline $\mathrm{LHRH}$ & 0 & $(0)$ & 5 & (4) & 0.87 \\
\hline Fulvestrant & 2 & (1) & 19 & $(15)$ & 0.86 \\
\hline \multicolumn{6}{|l|}{ Receipt of Chemotherapy } \\
\hline Category $A^{* *}$ & 85 & $(56)$ & 15 & $(12)$ & \\
\hline Category A + B & 32 & $(21)$ & 95 & $(77)$ & $<0.0001$ \\
\hline Receipt of HER2-directed therapy & 2 & (1) & 19 & $(15)$ & 0.17 \\
\hline \multicolumn{6}{|l|}{ Receipt of Bisphosphonates } \\
\hline Pamidronic acid & 8 & (5) & 37 & $(30)$ & 0.0007 \\
\hline Zoledronic acid & 3 & (2) & 35 & $(28)$ & 0.04 \\
\hline $\begin{array}{l}\text { Percentages reflect the proportion of } \\
\text { for ER, PR, and HER2 status. For these } \\
\text { respective period for whom patholog } \\
\text { * Period A encompasses patients diag } \\
1995 \text { and December } 31,2004 \text {. } \\
\text { ** See Table } 1 \text { for delineation of cyto }\end{array}$ & ubgr & $\begin{array}{l}\text { ng th } \\
\text { ber }\end{array}$ & & $\begin{array}{l}\text { i.e., Per } \\
\text { tal num } \\
\text { anose }\end{array}$ & $\begin{array}{l}\text { 3), except } \\
\text { n the } \\
\text { ry } 1 \text {, }\end{array}$ \\
\hline
\end{tabular}


metastasis (yes $v$ no), brain metastasis (yes $v$ no), bone metastasis (yes $v$ no), bone metastasis only (yes $v$ no), supraclavicular metastasis (yes $v$ no), soft tissue metastasis (yes $v$ no), receipt of endocrine therapy (yes $v$ no), receipt of SERMs (yes $v$ no), receipt of AIs (yes $v$ no), receipt of LHRH analogues (yes $v$ no), receipt of fulvestrant (yes $v$ no), receipt of chemotherapy (yes $v$ no), type of chemotherapy rendered (receipt of cytotoxic agents from Category A $v$ Categories A and B), receipt of HER2-directed therapy (yes $v$ no), receipt of bisphosphonate therapy (yes $v$ no), receipt of pamidronate acid (yes $v$ no), and receipt of zoledronic acid (yes $v$ no). Notably, with respect to ovarian suppression, only pharmacologic suppression with LHRH analogues was recorded; oophorectomy, ovarian ablation, and other surgical techniques were not captured. Variables bearing an association with survival with $\mathrm{P}<0.20$ were incorporated in a multivariate analysis using stepwise regression. Variables with a $\mathrm{P}<0.10$ were retained in the model. To examine the a priori hypothesis that advances in cytotoxic therapy have not resulted in $\mathrm{cu}-$ mulative improvements in survival, it was decided that the comparison of survival in patients receiving cytotoxic agents from Category A $v$ Category A and B would be retained in the multivariate model, irrespective of the result on univariate analysis.

\section{Results}

\section{Patient characteristics}

Of 324 consecutive patients with a diagnosis of de novo MBC, 274 are included in the analysis. Reasons for exclusion included supraclavicular nodal disease only $(n=29)$, misclassification of recurrent disease $(n=15)$, and patient refusal of consent for research use of clinical information $(n=6)$. Clinicopathologic and treatmentrelated data for all patients is summarized in Table 2. The median follow-up of survivors was 2.5 years for the overall population.

\section{Univariate analyses}

Univariate analyses of survival by clinicopathologic predictors are presented in Table 3. Patients diagnosed during period $\mathrm{B}$ had a slightly longer median survival as compared to patients treated during period $\mathrm{A}$, although this difference was not statistically significant (3.0 years vs 2.5 years, respectively; $\mathrm{P}=0.10)$. Among the clinicopathologic factors assessed, only ER status was significantly associated with improved survival (hazard ratio [HR] 0.69, 95\%CI 0.50-0.96; $\mathrm{P}=0.03)$. On the other hand, with treatment-related variables, multiple significant associations with survival were observed (Table 4). Treatment with endocrine therapy was associated with an improvement in survival $(\mathrm{HR}=0.60,95 \% \mathrm{CI} 0.47-0.77$; $\mathrm{P}<0.0001)$, and within this category, treatment with
Table 3 Univariate analyses comparing survival in patient subgroups stratified by clinicopathologic characteristics

\begin{tabular}{|c|c|c|c|}
\hline Characteristic & Hazard ratio & $95 \% \mathrm{Cl}$ & P-value \\
\hline \multicolumn{4}{|l|}{ Date of diagnosis } \\
\hline Period A & 1.00 & reference & 0.10 \\
\hline Period B & 0.95 & $0.92-1.00$ & \\
\hline \multicolumn{4}{|l|}{ Age (years) } \\
\hline$\leq 50$ & 1.00 & reference & 0.06 \\
\hline$>50$ & 1.27 & $1.00-1.63$ & \\
\hline \multicolumn{4}{|l|}{ Histology } \\
\hline Non-Inflammatory & 1.00 & reference & 0.21 \\
\hline Inflammatory & 1.22 & $0.88-1.69$ & \\
\hline \multicolumn{4}{|l|}{ ER Status } \\
\hline Negative & 1.00 & reference & 0.03 \\
\hline Positive & 0.69 & $0.50-0.96$ & \\
\hline \multicolumn{4}{|l|}{ PR Status } \\
\hline Negative & 1.00 & reference & 0.17 \\
\hline Positive & 0.8 & $0.59-1.09$ & \\
\hline \multicolumn{4}{|l|}{ HER2 Status } \\
\hline Negative & 1.00 & reference & 0.08 \\
\hline Positive & 0.55 & $0.28-1.08$ & \\
\hline \multicolumn{4}{|l|}{ Liver Mets } \\
\hline No & 1.00 & reference & 0.60 \\
\hline Yes & 1.08 & $0.80-1.44$ & \\
\hline \multicolumn{4}{|l|}{ Lung Mets } \\
\hline No & 1.00 & reference & 0.10 \\
\hline Yes & 1.25 & $0.95-1.65$ & \\
\hline \multicolumn{4}{|l|}{ Brain Mets } \\
\hline No & 1.00 & reference & 0.22 \\
\hline Yes & 1.43 & $0.80-2.56$ & \\
\hline \multicolumn{4}{|l|}{ Bone Mets } \\
\hline No & 1.00 & reference & 0.06 \\
\hline Yes & 1.29 & $0.98-1.70$ & \\
\hline \multicolumn{4}{|l|}{ Bone Only Mets } \\
\hline No & 1.00 & reference & 0.23 \\
\hline Yes & 0.83 & $0.62-1.12$ & \\
\hline \multicolumn{4}{|c|}{ Supraclavicular Node Mets } \\
\hline No & 1.00 & reference & 0.56 \\
\hline Yes & 0.92 & $0.69-1.22$ & \\
\hline \multicolumn{4}{|l|}{ Soft Tissue Mets } \\
\hline No & 1.00 & reference & 0.53 \\
\hline Yes & 1.11 & $0.78-1.59$ & \\
\hline
\end{tabular}

SERMs, AIs, and fulvestrant were each associated with improvements in survival $(\mathrm{P}=0.007, \mathrm{P}<0.0001$, and $\mathrm{P}=0.0004$, respectively). Although receipt of chemotherapy approached significance as a predictor of survival (HR 
Table 4 Univariate analyses comparing survival in patient groups stratified by treatment-related characteristics

\begin{tabular}{|c|c|c|c|}
\hline Characteristic & Hazard ratio & $95 \% \mathrm{Cl}$ & P-value \\
\hline \multicolumn{4}{|c|}{ Endocrine Therapy } \\
\hline No & 1.00 & reference & $<0.0001$ \\
\hline Any & 0.60 & $0.47-0.77$ & \\
\hline \multicolumn{4}{|l|}{ SERM } \\
\hline No & 1.00 & reference & 0.007 \\
\hline Yes & 0.63 & $0.48-0.82$ & \\
\hline \multicolumn{4}{|l|}{$\mathrm{Al}$} \\
\hline No & 1.00 & reference & $<.0001$ \\
\hline Yes & 0.47 & $0.34-0.66$ & \\
\hline \multicolumn{4}{|l|}{ LHRH } \\
\hline No & 1.00 & reference & 0.75 \\
\hline Yes & 0.85 & $0.31-2.30$ & \\
\hline \multicolumn{4}{|l|}{ Fulvestrant } \\
\hline No & 1.00 & reference & 0.0004 \\
\hline Yes & 0.29 & $0.15-0.57$ & \\
\hline \multicolumn{4}{|l|}{ Chemotherapy } \\
\hline No & 1.00 & reference & 0.06 \\
\hline Yes & 0.76 & $0.57-1.02$ & \\
\hline \multicolumn{4}{|l|}{ Category } \\
\hline A & 1.00 & reference & \\
\hline$A+B$ & 0.8 & $0.60-1.07$ & 0.13 \\
\hline \multicolumn{4}{|c|}{ HER2-Directed Therapy } \\
\hline No & 1.00 & reference & 0.15 \\
\hline Yes & 0.69 & $0.41-1.14$ & \\
\hline \multicolumn{4}{|c|}{ Bisphosphonate Therapy } \\
\hline No & 1.00 & reference & 0.02 \\
\hline Yes & 0.70 & $0.52-0.96$ & \\
\hline \multicolumn{4}{|l|}{ Pamidronic acid } \\
\hline No & 1.00 & reference & 0.44 \\
\hline Yes & 0.87 & $0.62-1.23$ & \\
\hline \multicolumn{4}{|l|}{ Zoledronic acid } \\
\hline No & 1.00 & reference & 0.002 \\
\hline Yes & 0.50 & $0.32-0.77$ & \\
\hline
\end{tabular}

0.76, 95\%CI 0.57-1.02; $\mathrm{P}=0.06$ ), there was no significant difference in survival among patients who received agents exclusively from Category A as opposed to both Category $A$ and $B(P=0.13)$. In the current analysis, patients receiving HER2-directed agents comprised a relatively small subset $(\mathrm{n}=21)$, challenging inferences in this subset. Lastly, bisphosphonate therapy was associated with improved survival (HR 0.70, 95\% CI 0.52-0.96; $\mathrm{P}=0.02$ ), and within this category, receipt of zoledronic acid was associated with the same (HR 0.50, 95\%CI 0.32-0.77; $\mathrm{P}=0.002$ ).

\section{Stepwise multivariate analysis}

In order to account for the possible confounding issues, the estimator for the variable of interest (Category A $v$ [Category A and B]) was examined. A model with all the terms was created and then each variable was taken out and the variable of interest's estimator was evaluated. Ultimately age, receipt of AI, and receipt of zoledronic acid were found to be independent significant predictors of survival; while category (i.e., Category A $v$ [Category A + B]) was not. The adjusted variables are listed in order of significance in Table 5.

\section{Discussion}

The impact of systemic therapy on the survival of women with metastatic breast cancer over time has been addressed by seven different investigators and these results are summarized in Table 6. All studies suggest that modest improvements in overall survival have been observed in recent years. An improvement in overall survival advantage is most pronounced in the trials where a higher percentage of women have hormone receptor-positive disease. We also observed a survival advantage for women with hormone receptor-positive disease and those who received an aromatase inhibitor. These observations are consistent with the published literature which demonstrates that a third generation aromatase inhibitor prolongs the survival of women with MBC compared with a progestational agent $[11,12]$.

The Hellenic Trialists compared the overall survival for women enrolled in 10 different treatment trials for $\mathrm{MBC}$ over a 15 year time interval and reported improving survivals over time [7]. This Greek series is confounded by the inclusion of women on trastuzumab-

Table 5 Multivariate analysis comparing survival in subgroups of patients with de novo MBC stratified by both clinicopathologic and treatment-related characteristics

\begin{tabular}{lccc}
\hline Characteristic & Hazard ratio & $\mathbf{9 5 \% ~ C l}$ & P-value \\
\hline Category & & & \\
$\mathrm{A}$ & 1.00 & reference & 0.76 \\
$\mathrm{~A}+\mathrm{B}$ & 1.04 & $0.77-1.40$ & \\
Age & & & \\
$<50$ & 1.00 & reference & 0.0008 \\
$\geq 50$ & 1.61 & $1.23-2.20$ & \\
$\mathrm{Al}$ & & & \\
No & 1.00 & reference & 0.0008 \\
Yes & 0.50 & $0.34-0.75$ & \\
Zoledronic acid & & & 0.005 \\
No & 1.00 & reference & \\
Yes & 0.45 & $0.26-0.79$ & \\
\hline
\end{tabular}


Table 6 Summary of trials addressing systemic therapy in advanced breast cancer

\begin{tabular}{|c|c|c|c|c|}
\hline Author, year & Institution(s)/ Database & Population & Time intervals & Comments \\
\hline \multirow[t]{2}{*}{ Andre, 2004 [5] } & \multirow[t]{2}{*}{ France (3 institutions) } & \multirow{2}{*}{$\begin{array}{l}724 \text { women de novo } \\
\text { metastatic breast cancer }\end{array}$} & 1987-1993 & \multirow{2}{*}{$\begin{array}{l}\text { Excluded supraclavicular } \\
\text { lymph node only patients. } \\
\text { Improved } 3 \text { year overall } \\
\text { survival (OS; } 44 \% \text { vs } 27 \% \text { ) } \\
\text { was seen in the more } \\
\text { recent time period. }\end{array}$} \\
\hline & & & $1994-2000$ & \\
\hline \multirow[t]{5}{*}{ Giordano, 2004 [9] } & \multirow{5}{*}{$\begin{array}{l}\text { MD Anderson } \\
\text { Cancer Center }\end{array}$} & \multirow{5}{*}{$\begin{array}{l}834 \text { women with recurrence } \\
\text { after adjuvant doxorubicin }\end{array}$} & 1974-1979 & \multirow{5}{*}{$\begin{array}{l}\text { Included patients with } \\
\text { locally recurrent disease. } \\
\text { Predictors of improved } \\
\text { overall survival included } \\
\text { stage at diagnosis, interval } \\
\text { disease-free survival, and } \\
\text { dominant metastatic site. }\end{array}$} \\
\hline & & & 1980-1984 & \\
\hline & & & 1985-1989 & \\
\hline & & & 1990-1994 & \\
\hline & & & $1995-2000$ & \\
\hline \multirow[t]{4}{*}{ Chia, 2007 [6] } & \multirow{4}{*}{$\begin{array}{l}\text { British Columbia } \\
\text { Cancer Agency }\end{array}$} & \multirow{4}{*}{$\begin{array}{l}2150 \text { women with both recurrent and } \\
\text { de novo metastatic breast cancer }\end{array}$} & 1991-1992 & \multirow{4}{*}{$\begin{array}{l}\text { An improvement in } \\
\text { overall survival was noted } \\
\text { over time, primarily in } \\
\text { those patients that were } \\
\text { hormone-receptor positive. }\end{array}$} \\
\hline & & & 1994-1995 & \\
\hline & & & 1997-1998 & \\
\hline & & & 1999-2001 & \\
\hline \multirow[t]{4}{*}{ Dawood, 2008 [13] } & \multirow{4}{*}{$\begin{array}{l}\text { Surveillance, Epidemiology, and } \\
\text { End Results Registry }\end{array}$} & \multirow{4}{*}{$\begin{array}{l}15,438 \text { women with both recurrent and } \\
\text { de novo metastatic breast cancer }\end{array}$} & 1988-1993 & \multirow{4}{*}{$\begin{array}{l}\text { There was a modest } \\
\text { improvement in overall } \\
\text { survival, associated with } \\
\text { patients with hormone- } \\
\text { receptor positive disease. } \\
\text { Outcomes appeared to } \\
\text { be worse in African } \\
\text { American women. }\end{array}$} \\
\hline & & & 1994-1998 & \\
\hline & & & 1999-2002 & \\
\hline & & & 2003-2006 & \\
\hline \multirow[t]{3}{*}{ Dafni, 2009 [14] } & \multirow[t]{3}{*}{ Hellenic Cooperative Group } & \multirow{3}{*}{$\begin{array}{l}1361 \text { enrolled on trials for } \\
\text { treatment of recurrent and } \\
\text { de novo metastatic breast cancer }\end{array}$} & 1991-1994 & \multirow{3}{*}{$\begin{array}{l}\text { Trastuzumab used in } \\
24 \% \text { and } 30 \% \text { of patients } \\
\text { in the two most recent } \\
\text { time intervals. }\end{array}$} \\
\hline & & & 1995-1998 & \\
\hline & & & $1999-2003$ & \\
\hline \multirow{3}{*}{$\begin{array}{l}\text { Ruiterkamp, } \\
2011[10]\end{array}$} & \multirow[t]{3}{*}{ Netherlands } & \multirow{3}{*}{$\begin{array}{l}8031 \text { women with both recurrent and } \\
\text { de novo metastatic breast cancer }\end{array}$} & 1995-1999 & \multirow{3}{*}{$\begin{array}{l}10 \% \text { of patients in } \\
\text { third time interval } \\
\text { received targeted } \\
\text { therapy. }\end{array}$} \\
\hline & & & $2000-2004$ & \\
\hline & & & $2005-2008$ & \\
\hline \multirow[t]{2}{*}{ Pal, 2011} & \multirow[t]{2}{*}{ City of Hope } & \multirow{2}{*}{$\begin{array}{l}274 \text { de novo metastatic } \\
\text { breast cancer only }\end{array}$} & 1985-1994 & \multirow{2}{*}{$\begin{array}{l}\text { Overall survival improved } \\
\text { for those receiving } \\
\text { endocrine therapy, } \\
\text { but no apparent overall } \\
\text { survival benefit with newer } \\
\text { chemotherapeutic agents. }\end{array}$} \\
\hline & & & $1995-2004$ & \\
\hline
\end{tabular}

containing regimens since 1999, a treatment that is unquestionably associated with an improved overall survival. In our series, the number of women receiving trastuzumab-containing chemotherapy was too small to demonstrate a survival advantage.

In our study and that of Andre, the trials included only patients who presented with de novo metastatic disease and reported an overall improvement in survival [5]. However, the survival advantage was largely attributed to benefits from endocrine therapy. We found no advantage to the use of the newer chemotherapeutic agents and Andre found no survival advantage for women with hormone receptor-negative disease [5].

We uniquely identified that the use of intravenous zoledronate was predictive of an improved survival. Given the lack of data supporting a survival advantage for bone-directed therapies in metastatic disease, we hypothesize that the improved survival observed is indicative of improved palliative care.

All the published series are retrospective reviews and the results are confounded by improvements in radiologic imaging, changes in the staging system, and potential for lead time bias. Some of the series included women with locally recurrent disease, a pattern of recurrence that is associated with a more favorable outcome. Only our study and that of Andre included only patients with de novo metastatic disease [5]. It remains uncertain if the natural history of de novo metastatic disease differs meaningfully from recurrent disease after treatment of early stage cancer. We are currently reviewing the outcome using the same analysis employed here to assess the impact of newer systemic therapy in women with recurrent MBC. We anticipate that this will provide additional hypothesis-generating data. 


\section{Conclusions}

In reviewing the available literature, it appears that advances in endocrine therapy and trastuzumab are largely responsible for overall survival improvements in the treatment of metastatic breast cancer. Improvements in endocrine therapy and the use of trastuzumab appear to have improved the survival of women with advanced breast cancer. The impact of conventional chemotherapy on survival appears to be minimal in the context of our retrospective cohort; perhaps these findings warrant more definitive exploration through the formation of multi-institution databases. These multi-institutional databases should include ideally include the same granularity of data as in our analysis and other, and should also capture surgical and radiation data to infer the benefits rendered from these modalities. Findings from such efforts could surely supplant the existent studies which draw from limited single-institution experiences.

\section{Competing interests}

The authors declare that they have no competing interests.

\section{Authors' contributions}

SKP, MD, RAN, SO, and JM participated in the conception and design of the project. SKP, MD, RAN, SO, SW, LK, and JM participated in data collection. SKP, MD, RAN and JM participated in data analysis. SKP, MD, RAN, SO, JH, SW LK and JM participated in the writing of the manuscript, and all authors had final approval of the submitted manuscript.

\section{Acknowledgements}

Dr. Pal's efforts are supported by CBCRP 15IB-0140 (California Breast Cancer Research Program Junior IDEA Award), the NIH Loan Repayment Plan (LRP) and NIH K12 2K12CA001727-16A1.

\section{Author details}

'Division of Genitourinary Malignancies, Department of Medical Oncology \& Experimental Therapeutics, City of Hope Comprehensive Cancer Center, Duarte, CA, USA. ²Department of Biostatistics, City of Hope Comprehensive Cancer Center, Duarte, CA, USA. ${ }^{3}$ Department of Surgery, City of Hope Comprehensive Cancer Center, Duarte, CA, USA.

Received: 9 March 2012 Accepted: 26 September 2012

Published: 28 September 2012

\section{References}

1. Early Breast Cancer Trialists' Collaborative G: Comparisons between different polychemotherapy regimens for early breast cancer: metaanalyses of long-term outcome among 100,000 women in 123 randomised trials. Lancet 2012, 379:432-444.

2. Slamon DJ, Leyland-Jones B, Shak S, et al: Use of chemotherapy plus a monoclonal antibody against HER2 for metastatic breast cancer that overexpresses HER2. N Engl J Med 2001, 344:783-792.

3. Cortazar P, Zhang JJ, Sridhara R, Justice RL, Pazdur R: Relationship between OS and PFS in metastatic breast cancer (MBC): Review of FDA submission data. ASCO Meeting Abstracts 2011, 29:1035.

4. Montero AJ, Vogel C: Fighting Fire with Fire: Rekindling the Bevacizumab Debate. N Engl J Med 2012, 366:374-375.

5. Andre F, Slimane K, Bachelot T, et al: Breast Cancer With Synchronous Metastases: Trends in Survival During a 14-Year Period. J Clin Oncol 2004, 22:3302-3308

6. Chia SK, Speers CH, D'yachkova Y, et al: The impact of new chemotherapeutic and hormone agents on survival in a populationbased cohort of women with metastatic breast cancer. Cancer 2007 110:973-979.
7. Dafni U, Grimani I, Xyrafas A, Eleftheraki AG, Fountzilas G: Fifteen-year trends in metastatic breast cancer survival in Greece. Breast Cancer Res Treat 2010, 119:621-631.

8. Dawood S, Broglio K, Gonzalez-Angulo AM, Buzdar AU, Hortobagyi GN, Giordano SH: Trends in survival over the past two decades among white and black patients with newly diagnosed stage IV breast cancer. J Clin Oncol 2008, 26:4891-4898.

9. Giordano SH, Buzdar AU, Smith TL, Kau S-W, Yang Y, Hortobagyi GN: Is breast cancer survival improving? Cancer 2004, 100:44-52

10. Ruiterkamp J, Ernst MF, de Munck $L$, et al: Improved survival of patients with primary distant metastatic breast cancer in the period of 1995-2008. A nationwide population-based study in the Netherlands. Breast Cancer Res Treat 2011, 128:495-503.

11. Buzdar A, Jonat W, Howell A, et al: Anastrozole, a potent and selective aromatase inhibitor, versus megestrol acetate in postmenopausal women with advanced breast cancer: results of overview analysis of two phase III trials. Arimidex Study Group. J Clin Oncol 1996, 14:2000-2011.

12. Kaufmann M, Bajetta $E$, Dirix LY, et al: Exemestane is superior to megestrol acetate after tamoxifen failure in postmenopausal women with advanced breast cancer: results of a phase III randomized double-blind trial. The Exemestane Study Group. J Clin Oncol 2000, 18:1399-1411.

13. Dawood S, Broglio K, Gonzalez-Angulo AM, Buzdar AU, Hortobagyi GN, Giordano SH: Trends in Survival Over the Past Two Decades Among White and Black Patients With Newly Diagnosed Stage IV Breast Cancer. J Clin Oncol 2008, JCO.2007.14.1168.

14. Dafni U, Grimani I, Xyrafas A, Eleftheraki A, Fountzilas G: Fifteen-year trends in metastatic breast cancer survival in Greece. Breast Cancer Res Treat 2010, 119:621-31.

doi:10.1186/1471-2407-12-435

Cite this article as: Pal et al:: Impact of modern chemotherapy on the survival of women presenting with de novo metastatic breast cancer. BMC Cancer 2012 12:435.

\section{Submit your next manuscript to BioMed Central and take full advantage of:}

- Convenient online submission

- Thorough peer review

- No space constraints or color figure charges

- Immediate publication on acceptance

- Inclusion in PubMed, CAS, Scopus and Google Scholar

- Research which is freely available for redistribution 